\title{
Using Technological Innovation and Corporate Social Responsibility to Connect Africa's Smallholder Farmers to the Global Sustainable Agriculture Economy
}

\author{
Authors: Amenawon Igharo ${ }^{1}$, Sean Meriwether ${ }^{2}$, and Lynnette Widder ${ }^{3}$ \\ \{aci2111@columbia.edu ${ }^{1}$, spm2163@columbia.edu²,1w268@columbia.edu $\left.{ }^{3}\right\}$ \\ Graduate Student, Columbia University Master of Sustainability Management, New York, NY $10027^{1}$ \\ Graduate Student, Columbia University Master of Sustainability Management, New York, NY $10027^{2}$ \\ Lecturer, Columbia University Master of Sustainability Management, New York, NY $10027^{3}$
}

\begin{abstract}
Smallholder farmers commonly use sustainable farming practices out of tradition or financial necessity, but are not participating in the global sustainable agriculture economy. At the same time, increased awareness of social and environmental issues and growing consumer influence have encouraged corporations to engage in social entrepreneurship and/or use sustainably-sourced products in their supply chain. Currently each company must conduct its own research to source the agricultural commodities that it needs and develop relationships with its sources, slowing broadscale adoption. A framework to bridge these two groups in mutually beneficial relationships is being developed by adapting existing technology in innovative ways to leverage native knowledge as a common good while simultaneously connecting smallholders with corporate social responsibility (CSR) programs to fulfill their companies' missions.
\end{abstract}

Keywords. Africa. Cell phone. Connectivity. Corporate social responsibility. Food security. Innovation. Lean data. Radio play. Reforestation. Smallholder farmers. Smartphone. Sustainable agriculture economy. Technology. Traditional knowledge. Uganda. Responsible Sourcing. Sustainable Sourcing. Value chain.

\section{The Disconnect Between Smallholders and the Global Sustainable Agriculture Economy}

The Food and Agriculture Organization (FAO) of the United Nations has defined sustainable agriculture as the management and conservation of natural resources, to ensure the fulfillment of present human needs while 
protecting the needs of future generations. ${ }^{1}$ Sustainable agriculture's mission is to produce sufficient food to feed the growing population while reducing negative impact on the ecosystem with measures such as restricting the use of petroleum-based inputs (i.e. fertilizer and pesticide), water conservation, eliminating tillage to reduce soil erosion, and expanding crop diversity with local species. It blends traditional farming methods with a scientific approach, placing a heavy emphasis on measurement, from soil health metrics to yield per acre, to validate the positive impact sustainable agriculture has on the ecosystem, the food chain, and society with improved health, productivity, and food security.

Smallholder farms in Africa average less than two hectares ${ }^{2}$ and many smallholders employ traditional methods which run parallel to sustainable agriculture. They rely on intergenerational knowledge, individual innovation, and personal experience to cultivate their crops without overtaxing the ecosystem. Smallholders may work their plots by hand and use close observation to track the health of their soil and crops. While labor intensive, close observation and reliance on traditional practices increases profit by reducing or eliminating the cost of chemical inputs, and allowing for a degree of responsiveness that additive-dependent (i.e. fertilizers) or industrial scale agriculture cannot match. Although smallholders are credited with producing 70 percent of the world's food, ${ }^{3}$ they are unlikely to be included in the sustainable agriculture equation because they are not marketing their efforts as sustainable. However, the industry would benefit from smallholder innovations and cumulative native knowledge, especially with regard to climate change, since African farmers are adapting to recent changes in growing conditions, including rising temperatures and disruptions in the water cycle. ${ }^{4}$

Smallholders face many obstacles to joining the global sustainable agriculture economy. Smallholder farms are family-run enterprises in which the bulk of time is spent on the cultivation and harvesting of crops. Farmers may be

\footnotetext{
${ }^{1}$ Author unknown: Sustainability assessment of food and agriculture systems guidelines (version 3). p 2. Food and Agriculture Organization of the United Nations (2013). Retrieved from: http://www.fao.org/fileadmin/templates/nr/sustainability_pathways/docs/SAFA_Guidelines_Final_122013.pdf

2 Rapsomanikis, G.: The economic lives of smallholder farmers. p 5. Food and Agriculture Organization of the United Nations (2015). Retrieved from: http://www.fao.org/3/a-i5251e.pdf

${ }^{3}$ Maass Wolfenson, K.: Coping with the food and agriculture challenge: smallholders' agenda. p 22. Preparations and Outcomes of the 2012 United Nations Conference on Sustainable Development (2013). Retrieved from:

http://www.fao.org/fileadmin/templates/nr/sustainability_pathways/docs/Coping_with_food_and_agriculture_challenge_Smallh older_s_agenda_Final.pdf

${ }^{4}$ Mabiru, DN. Climatic trends, risk perceptions and coping strategies of smallholder farmers in rural Uganda. Working Paper No. 121. p 36. CGIAR Research Program on Climate Change, Agriculture and Food Security (2015). Retrieved from: https://cgspace.cgiar.org/rest/bitstreams/56351/retrieve
} 
isolated by distance, language, or lack awareness about the benefits of participating in the global sustainable agriculture economy. One of the main obstacles smallholders face is data collection. Measuring, tracking, and reporting performance are critical to documenting sustainable farming practices. Without a means to validate their practices or document their contribution to protecting the ecosystem, smallholders may lose valuable incentives to maintain their practices - to the detriment of local economies and global sustainability.

Technology is upending this equation. Africa is leapfrogging over the developed world by forgoing landlines and investing in infrastructure to support digital connectivity. Cell phone ownership has exploded across Africa. ${ }^{5}$ Cell phones are in the hands of approximately 1.2 billion Africans, but are concentrated among wealthier urbanites who have more consistent service. However, connectivity is expanding into rural areas at increasingly lower costs. ${ }^{6}$ The broad adoption of cell phones offers an opportunity to connect farmers with information, CSR programs, and empower them to become valuable data collection points. A number of customer research firms are using the messaging service on cell phones to collect and aggregate data from smallholders, such as monitoring water conditions, soil health, or tracking crops coming to the market. Smartphones and improved connectivity will provide additional resources to farmers, such as image capabilities, accessing online information, and microbanking. An advantage of leveraging cell phones is that it is a technology that smallholders are familiar with and want to own, which will increase the likelihood of them adopting new applications on their devices.

Creating a framework to easily measure and report data via cell phone or smartphone, aggregating the inputs individually and regionally, could help smallholders with the reporting and measurements required by sustainable agriculture, while allowing for CSR programs to identify sustainably sourced commodities for their supply chain. For example, by providing smallholders with basic soil testing kits to measure the levels of nitrogen, potassium, phosphorus, and acidity $(\mathrm{pH})$, farmers could track soil health. Test results could be reported on a periodic basis via text message to monitor land management practices, which could stand as a proxy for ecosystem health. Such proxies followed over time can record the state of ecosystems services which, in their accrued form, carry monetary and social value in the global sustainable agriculture economy.

\footnotetext{
5 Author unknown.: "Cell phones in Africa: communication lifeline". Pew Research Center. April 15, 2015. Retrieved from: http://www.pewglobal.org/2015/04/15/cell-phones-in-africa-communication-lifeline

6 Author unknown.: "Mobile phones are transforming Africa". The Economist. December 10, 2016. Retrieved from: https://www.economist.com/news/middle-east-and-africa/21711511-mobile-phones-are-transforming-africa-where-they-can-getsignal-mobile-phones
} 


\section{Plugging Smallholder Farmers into the Global Supply Chain}

CSR and Expanding Supply Chain. There are a myriad of innovations targeting smallholders on the African

continent to help connect them with the global supply chain. These innovations are creating opportunities for corporate CSR departments to support sustainable development by encouraging the transfer of knowledge, financing the adoption of innovation and tackling food security issues for smallholder farmers. Research shows success in leveraging knowledge as a common good to foster competitiveness in the agricultural sector ${ }^{7}$ and for sustainable development. The GIZ Competitive Cashew Initiative (ComCashew) is an example of how corporate CSR departments can capitalize on these lessons. ComCashew is part of the German Corporation for International Cooperation GmbH (GIZ) program on Broad-scale Promotion of Agricultural Value Chains in Africa. It is a multistakeholder partnership that aims to reduce poverty, and improve nutrition among smallholder farmer households by enhancing the competitiveness of the cashew sector. ${ }^{8}$

Since 2009, GIZ has trained 480,000 farmers in agricultural harvest and postharvest practices. They also implemented a master training program that has trained 180 trainers in 12 African countries on the cashew value chain and on policy. These training programs build national and regional networks for future collaboration and facilitate the discussion of best practices, lessons learned and innovation in the cashew sector. ${ }^{9}$ ComCashew's initiatives help farmers - particularly women — access a new source of income, improve quality, and increase yield by an average of 75 percent. It also offers $1.5 \mathrm{M}$ farmers in Africa new economic opportunities in the cashew value chain including over 400,000 jobs in production, processing and trade. ComCashew partners with public and private stakeholders including Walmart, InterSnack, and KraftHeinz, to usher in systems-level change by providing smallholder farmers the knowledge and skills they need to participate in the global sustainable cashew sector.

ComCashew's initiative highlights how the involvement of corporate CSR can scale knowledge transfer programs and how multi-stakeholder partnerships can create impactful sustainable development initiatives. The Great Green Wall (GGW) is a similar knowledge transfer initiative that is a community-led reforestation initiative in Niger and

\footnotetext{
${ }^{7}$ Mancini, C., Kidane, Y., Mengistu, D., Melfa and Workaye Farmer Community, Pe, M., Fadda, C., and Dell'Acqua, M.: Joining smallholder farmers' traditional knowledge with metric traits to select better varieties of Ethiopian wheat. $\mathrm{p}$ 4-8. Scientific Reports (2017). Retrieved from: https://www.nature.com/articles/s41598-017-07628-4.pdf

${ }^{8}$ Author unknown.: ComCashew website. (2017). Retrieved from: http://www.africancashewinitiative.org

9 Author unknown.: "ComCashew holds training program in cashew value chain promotion". Citifmonline. August 7 , 2017.Retrieved from: http:/citifmonline.com/2017/08/07/comcashew-holds-training-program-in-cashew-value-chain-promotion/
} 
Burkina Faso. The regreening project originated in Niger with Tony Rinaudo from Serving Mission, an Australian religious nonprofit. Mr. Rinaudo worked with farmers to identity useful native tree species and modify traditional agricultural practices to plant and nurture the trees. Mature trees provide communities with fuel, livestock fodder, nutritious leaves and nuts for consumption, as well as retain moisture in the soil, reduce erosion from desertification, and create shady areas to grow crops. As a result, fields of grains are once again growing in the desert. ${ }^{10}$ In the three decades since Mr. Rinaudo's work with the community in Niger, information on the benefits of reforestation has spread organically from farmer to farmer. The GGW offers corporate CSR departments an opportunity to partner on and rapidly scale a successful innovation that makes knowledge a common good, improves the lives of smallholders and increases the amount of agricultural commodities available in the market.

\section{Technology Connecting Smallholders to Financing and Productivity.}

A technological innovation that allows farmers to benefit from their knowledge is Gro Intelligence (GI). GI's project is to reform the agricultural system in Africa, creating the first model where smallholder farming can co-exist with commercial agriculture. GI has developed a subscription-based software called Clews, which is a search engine that accesses a broad range of agricultural data including open source satellite imagery, trade flows, and farmergenerated information. This service is being marketed to corporations and governments. The Ethiopian founder of GI, Sara Menker, a former commodities trader believes that agriculture is a very fragmented industry and information about it has been captured in a fragmented, disorganised way. ${ }^{11}$ According to Menker, despite accounting for 65 percent of the labor force and 32 percent of its gross domestic product - Africa's agricultural sector gets less than one percent of commercial bank loans. That lack of capital is a barrier that limits the ability of farmers and the industry to improve production, tackle food security issues and address poverty reduction goals. ${ }^{12}$

Data collection from smallholder farmers is critical for food systems. ${ }^{13}$ By collecting data from a network of farmers, GI can create credit models that banks can use to vet farmers for loans, including pooled lending. This will

\footnotetext{
${ }^{10}$ Morrison, J.: “The 'Great Green Wall' didn't stop desertification, but it evolved into something that might”. Smithsonian. August 23, 2016. Retrieved from: http://www.smithsonianmag.com/science-nature/great-green-wall-stop-desertification-not-somuch-180960171/\#U3BJb8V4qqYyLVU6.99

${ }^{11}$ Daneshkhu, S.: "The appliance of agricultural science”. Financial Times. November 30, 2016. Retrieved from: https://www.ft.com/content/80bea758-a691-11e6-8898-79a99e2a4de6

12 Saldinger, A.: “Can data-driven solutions change Africa's agricultural sector?”. Devex. October 25, 2013. Retrieved from: https://www.devex.com/news/can-data-driven-solutions-change-africa-s-agriculture-sector-82172

${ }^{13}$ Waha,K., Zipf,B., Kurukulasuriya, P., and Hassan, R.: An agricultural survey for more than 9,500 African households. p 4-7. Scientific Data (2016). Retrieved from: https://www.ncbi.nlm.nih.gov/pmc/articles/PMC4878200/pdf/sdata201620.pdf
} 
allow a farming community to collaboratively purchase an expensive piece of farm equipment to be used by the contributing farmers. ${ }^{14}$ Menker believes that the farmer is the most underutilized source of information in the whole puzzle as they are the best sensor you can have and can answer very simple questions like, What are you planting? What have you sold today? ${ }^{15}$ Partnerships are key to GI achieving their goal.

Paying farmers for their information, establishes the value of their data and their knowledge. Corporations that purchase GI's Clews software are encouraging the sharing of data and traditional knowledge amongst community members in order to access collective financing thereby increasing fair competition and achieving sustainable development. Financing would allow smallholder farmers to access new tools targeting them such as Digital Farmhand (DF). DF promises to help smallholders manage the arduous work of farming. This mobile system is in prototype stage, but will provide crop intelligence, connect smallholders with a global growing community, and increase farmers' capacity to produce nutritious foods by utilizing data analytics and robotics. ${ }^{16}$ It was developed by an expert in robotics, Professor Salah Sukkarieh at the University of Sydney. Recognizing that commercial farming equipment was not suited nor affordable for low income farmers, he believes digital tools could help farmers increase productivity at an affordable cost.

DF is a portable device that can be hand-towed, remotely controlled, or set to an autonomous mode. The device consists of a smartphone, sensors, and an on-board computer. The system can undertake precision seeding, spraying and weeding, and can monitor individual plants by using imaging capabilities. DF has the potential to support better decision making, help increase productivity, reduce input costs, and maximize food security. ${ }^{17}$ Small scale farming is laborious and the difficulty of the work is often cited as one of the reasons younger Africans choose to seek work in urban areas. ${ }^{18} \mathrm{DF}$ is an innovation that will reduce the arduousness of the work, making farming more appealing to a tech-savvy younger generation.

\footnotetext{
${ }^{14}$ Byrne, C.: "Data-driven lending could help African farmers feed the world". Fast Company. October 14, 2013. Retrieved from: https://www.fastcompany.com/3019953/data-driven-lending-could-help-african-farmers-feed-the-world

${ }^{15}$ Menker, S.: "A global food crisis may be less than a decade away". TED. (2017) Retrieved from: https://www.ted.com/talks/sara_menker_a_global_food_crisis_may_be_only_a_decade_away

${ }^{16}$ Author unknown.: Launch website. (2017). Retrieved from: https://www.launch.org/innovators/salah-sukkarieh

17 Author unknown.: The Crawford Fund website. (2017) Retrieved from: https://www.crawfordfund.org/events/2017conference/speakers/prof-salah-sukkarieh/

${ }^{18}$ Menker, S.: "A global food crisis may be less than a decade away". TED. (2017) Retrieved from: https://www.ted.com/talks/sara_menker_a_global_food_crisis_may_be_only_a_decade_away
} 


\section{Communicating Opportunities for Innovation}

Scaling transformative innovation to reach farmers across the continent remains a challenge. Corporate CSR could contribute to increasing awareness on how smallholder farmers can connect to global sustainable supply chains and access technology innovations. As ComCashew shows with its master trainer program, it would be impossible to conduct one-on-one training with every smallholder farmer, and prohibitively expensive to provide all farmers with smartphones, especially in regions with limited connectivity where they would add little value. This obstacle is being addressed by building services that work with basic cell phones to offer a reliable and inexpensive method to connect farmers with programs and initiatives. However, farmers also need to be aware these initiatives exist in order to connect with them. Reaching rural smallholders to increase awareness about new innovations offers an opportunity for corporations to leverage their marketing capabilities to maximize a deeply entrenched but overlooked technology for making traditional knowledge a common good; radio. ${ }^{19}$ Radios are prevalent across Africa and can run on batteries or solar cells. UNESCO estimates that 73 percent of farmers own a radio. ${ }^{20}$ Although vital information, such as weather reports, farming innovations, and market prices are broadcast on the radio, smallholder farmers may not be tuning in. They may be more inclined to listen to the radio for entertainment.

Mexican telenovelas have become popular in East Africa and a cottage industry has emerged to translate and produce shows in local languages. The storylines resonate with the population due to their aspirational nature and dramatic tales of woe. ${ }^{21}$ Television is a rare commodity in rural homes but radios offer an alternative method to reach remote listeners. Informative radio plays with plotlines similar to telenovelas can raise awareness of farming innovations and share knowledge in an entertaining format that honors the continent's storytelling cultural history.

For example, a storyline could feature an urban couple returning to the village to become sustainable farmers. These hapless new farmers would attempt various innovations, allowing an opportunity for a knowledgeable farmer to step in and share traditional methods and techniques. The episodes would end with a cliffhanger where the couple is forced to choose the best practice to grow supply chain quality produce. Leveraging the popularity of local DJs,

\footnotetext{
${ }^{19}$ Kumari, N., Choudhary, S.B., Jha, S.K., and Singh, S.R.K.: Radio: An educational media to transfer agricultural information among farmers. p 139-140. SEEA (2014). Retrieved from: http://seea.org.in/ojs/index.php/irjee/article/viewFile/203/202

${ }^{20}$ Author unknown: World Radio Day, 13 February, 2017. United Nations Educational, Scientific and Cultural Organization. Retrieved from: http://www.diamundialradio.org/node/18

${ }^{21}$ Peralta, E.: "Why East Africa is hooked on telenovelas". NPR. June 5, 2017. Retrieved from: http://www.npr.org/sections/goatsandsoda/2017/06/05/529683214/why-east-africa-is-hooked-on-telenovelas
} 
listeners would be encouraged to call or text in with suggestions on best practices - sparking conversation. Programming could be tailored to regional and ethnic differences and could be sponsored by corporate CSR departments to advertise their products or technological innovations to African farmers.

Research is needed to confirm if the radio plays would effectively engage smallholders, and partnerships would need to be developed with CSR departments and governments to support production costs, but this is one approach to reach millions of smallholders across the African continent, preserve and share traditional knowledge, and connect farmers with the global sustainable agriculture economy. ${ }^{22,23}$

\section{Case Study: Sustainably Sourced Food in Search of the Global Market}

In the spring of 2017 the authors of this paper worked with the nonprofit A Growing Culture, which is an advocate for documenting, sharing, and championing smallholder knowledge and innovation worldwide. The authors were invited to a farming village, Kasejjere, located $80 \mathrm{~km}$ west of the capital of Uganda, to interview participating farmers and learn about their sustainable farming practices.

Years of clearcutting to raise a single variety of banana, used in the production of liquor, had nearly destroyed the rural village. The people of Kasejjere faced food scarcity, depleted soil and erosion. A community based organization, The Kikandwa Environmental Association (KEA), was formed to encourage farmers to adopt sustainable farming practices, expand crop diversity with native varieties and sustenance foods, reforest areas to reduce soil erosion, and use organic fertilizers. In the seventeen years since KEA's founding, the farming community has repaired the soil, expanded use of native crop species, improved quality and quantity of their harvests, and reforested areas with beneficial trees. These efforts improved food security and living conditions in the village. KEA's success combined with the international outreach efforts of co-founder, John Kaganga, has helped Kasejjere's smallholders connect to the sustainable agriculture community to share their knowledge.

\footnotetext{
${ }^{22}$ Ariyo, O.C., Ariyo, M.O., Okelola, O.E., Aasa, O.S., Awotide, O.G., Aaron, A.J., and Oni, O.B.: Assessment of the role of mass media in the dissemination of agricultural technologies among farmers in Kaduna north local government area of Kaduna State, Nigeria. p 22-24 Journal of Biology, Agriculture and Healthcare (2013). Retrieved from: http://www.iiste.org/Journals/index.php/JBAH/article/viewFile/5677/5790

${ }^{23}$ Lucas, F..: “A Radio Broadcasting Model for Rural Women and Farm Households". FAO. January, 1999. Retrieved from: http://www.fao.org/docrep/005/ac789e/AC789E00.htm\#TOC
} 
Despite these advances, due to their remote location and lack of connectivity the participating farmers remain dependent on middlemen who purchase their crops, cart them to the distant capital, and sell them at a markup. The farmers of Kasejjere felt they had little control over the price they could charge for their produce. If the community were connected to the global sustainable agriculture economy, they might have other outlets, potentially at a fair trade rate. For instance, almost all of the participating farmers grew the same narrow range of crops, which put them in competition with one another and smallholders closer to the city. Instead, they might also work collaboratively to provide sustainably sourced goods, such as coffee, spices, or botanicals, to corporations requiring them for their supply chain.

The participating farmers that were interviewed expressed an interest in innovations that could reduce the labor component of farming. For example, the government had one tractor available in each district but it was hard to access due to high demand during planting season. Pooled lending could help them purchase a tractor for the village. The farmers also understood that their sustainable farming knowledge had value to other smallholders and the sustainable agriculture community; and were interested in exploring sales of nonperishable value-add products, such as amaranth porridge, honey, and dried fruits. However, they were uncertain how to proceed.

During the interviews, the farmers discussed some other barriers that they faced, including: how to create value through maintaining sustainable farming practices; how to gain access to and finance innovations that could improve their lives; how to access markets directly without middlemen cutting into their profit; and how to avoid personal risk to their primary source of sustenance and income. Helping smallholders overcome these barriers is an opportunity for CSR departments. Corporations can help farmers by connecting with them, placing a value on their knowledge and products, and scaling up awareness of innovations while ensuring smallholders retain their autonomy and traditions.

In Kasajerre, the method of preserving and sharing traditional farming techniques was through a knowledge leader, Salongo Kakembo. Kakembo is a resource for other farmers, offering his expert advice on a plethora of issues, including what to plant, how to preserve seeds, and how to intercrop and mulch. He inherited this role in the community from his grandmother. He manages the community test farm in addition to his own plot of land, using practices such as not tilling the soil and growing heritage varieties. The test farm was in the center of the community and exemplified the most beneficial sustainable farming practices to be replicated that could improve a farmer's 
harvest with less labor and requiring no chemical inputs. Research from International Initiative for Impact Evaluation (3IE) indicates that test farms resulted in an 35 percent increase in income for participating farmers. ${ }^{24}$ In collaboration with KEA, Kakembo also runs a seedling farm that provides free saplings for the village's reforestation initiative, Half + Half, which encourages farmers to set aside a portion of their land for beneficial trees to protect the moisture in the soil, prevent erosion, positively adjust nitrogen levels, protect biodiversity, and provide shade for crops, similar to the goals of the GGW project.

Connecting community experts like Kakembo to the global sustainable agriculture economy would allow him to share his extensive knowledge beyond the borders of his village, as well as become an contact point for receiving information about resources and innovations that he could share with local farmers. Arming him with a cell phone or smartphone to facilitate that connection and building his awareness of the innovations available would expedite the collaboration. Uniting the smallholders of Kasejjere in working with companies looking for sustainably sourced goods would allow the village to take the next step up the economic rung toward prosperity.

\section{Conclusion}

Even as activity and innovation grows in the field of sustainable agriculture, the connection between international actors and smallholders remains frail. Inadequate communication, measurement, and recording impede the ability of smallholders to advocate for themselves and the benefits of their practices. The fragmented nature of their business makes negotiation with multinationals, for whom a fractured supply chain is a liability, even more difficult. Nonetheless, the social, environmental, and food security-based advantages of a vibrant smallholder population cannot be overstated. Closing the distance between the corporate social responsibility departments of corporations and smallholders requires a new generation of agents knowledgeable about global supply chain management who are invested in the smallholder community. By aggregating individual farms, creating and sustaining relationships with communities, and translating the language and metrics of these diverse groups, this new cadre of international actors could ensure that the people who provide 70 percent of the world's food are also the beneficiaries of the largess the world enjoys at their expense.

${ }^{24}$ Stewart, R., Langer, L., Da Silva, N.R., Muchiri, E.: Effects Of Training, Innovation and New Technology on African Smallholder Farmers' Economic Outcomes and Food Security. Systematic Review Summary 6. p 10-15. 3ie International Initiative for Impact Evaluation, UK (2016). Retrieved from: http://www.3ieimpact.org/media/filer_public/2016/07/14/srs6africa-smallholder-farmers.pdf 


\section{References}

[1] Author unknown: Sustainability assessment of food and agriculture systems guidelines (version 3). p 2. Food and Agriculture Organization of the United Nations (2013). Retrieved from:

http://www.fao.org/fileadmin/templates/nr/sustainability_pathways/docs/SAFA_Guidelines_Final_122013.pdf

[2] Rapsomanikis, G.: The economic lives of smallholder farmers. p 5. Food and Agriculture Organization of the United Nations (2015). Retrieved from: http://www.fao.org/3/a-i5251e.pdf

[3] Maass Wolfenson, K.: Coping with the food and agriculture challenge: smallholders' agenda. $\mathrm{p} 22$. Preparations and Outcomes of the 2012 United Nations Conference on Sustainable Development (2013). Retrieved from:

http://www.fao.org/fileadmin/templates/nr/sustainability_pathways/docs/Coping_with_food_and_agriculture_challenge_Smallh older_s_agenda_Final.pdf

[4] Mabiru, DN. Climatic trends, risk perceptions and coping strategies of smallholder farmers in rural Uganda. Working Paper No. 121. p 36. CGIAR Research Program on Climate Change, Agriculture and Food Security (2015). Retrieved from: https://cgspace.cgiar.org/rest/bitstreams/56351/retrieve

[5] Author unknown.: "Cell phones in Africa: communication lifeline". Pew Research Center. April 15, 2015. Retrieved from: http://www.pewglobal.org/2015/04/15/cell-phones-in-africa-communication-lifeline

[6] Author unknown.: "Mobile phones are transforming Africa". The Economist. December 10, 2016. Retrieved from: https://www.economist.com/news/middle-east-and-africa/21711511-mobile-phones-are-transforming-africa-where-they-can-getsignal-mobile-phones

[7] Mancini, C., Kidane, Y., Mengistu, D., Melfa and Workaye Farmer Community, Pe, M., Fadda, C., and Dell'Acqua, M.: Joining smallholder farmers' traditional knowledge with metric traits to select better varieties of Ethiopian wheat. p 4-8. Scientific Reports (2017). Retrieved from: https://www.nature.com/articles/s41598-017-07628-4.pdf

[8] Author unknown.: ComCashew website. (2017). Retrieved from: http://www.africancashewinitiative.org

[9] Author unknown.: "ComCashew holds training program in cashew value chain promotion". Citifmonline. August 7 ,

2017.Retrieved from: http:/citifmonline.com/2017/08/07/comcashew-holds-training-program-in-cashew-value-chain-promotion/ [10] Morrison, J.: "The 'Great Green Wall' didn't stop desertification, but it evolved into something that might”. Smithsonian. August 23, 2016. Retrieved from: http://www.smithsonianmag.com/science-nature/great-green-wall-stop-desertification-not-somuch-180960171/\#U3BJb8V4qqYyLVU6.99

[11] Daneshkhu, S.: “The appliance of agricultural science”. Financial Times. November 30, 2016. Retrieved from: https://www.ft.com/content/80bea758-a691-11e6-8898-79a99e2a4de6

[12] Saldinger, A.: “Can data-driven solutions change Africa's agricultural sector?”. Devex. October 25, 2013. Retrieved from: https://www.devex.com/news/can-data-driven-solutions-change-africa-s-agriculture-sector-82172 
[13] Waha,K., Zipf,B., Kurukulasuriya, P., and Hassan, R.: An agricultural survey for more than 9,500 African households. p 47. Scientific Data (2016). Retrieved from: https://www.ncbi.nlm.nih.gov/pmc/articles/PMC4878200/pdf/sdata201620.pdf

[14] Byrne, C.: "Data-driven lending could help African farmers feed the world”. Fast Company. October 14, 2013. Retrieved from: https://www.fastcompany.com/3019953/data-driven-lending-could-help-african-farmers-feed-the-world [15] Author unknown.: Launch website. (2017). Retrieved from: https://www.launch.org/innovators/salah-sukkarieh [16] Author unknown.: The Crawford Fund website. (2017) Retrieved from: https://www.crawfordfund.org/events/2017conference/speakers/prof-salah-sukkarieh/

[17] Menker, S.: “A global food crisis may be less than a decade away". TED. (2017) Retrieved from:

https://www.ted.com/talks/sara_menker_a_global_food_crisis_may_be_only_a_decade_away

[18] Kumari, N., Choudhary, S.B., Jha, S.K.,and Singh, S.R.K.: Radio: An educational media to transfer agricultural information among farmers. p 139-140. SEEA (2014). Retrieved from:

http://seea.org.in/ojs/index.php/irjee/article/viewFile/203/202

[19] Author unknown: World Radio Day, 13 February, 2017. United Nations Educational, Scientific and Cultural Organization. Retrieved from: http://www.diamundialradio.org/node/18

[20] Peralta, E.: "Why East Africa is hooked on telenovelas". NPR. June 5, 2017. Retrieved from: http://www.npr.org/sections/goatsandsoda/2017/06/05/529683214/why-east-africa-is-hooked-on-telenovelas [21] Ariyo, O.C., Ariyo, M.O., Okelola, O.E., Aasa, O.S., Awotide, O.G., Aaron, A.J., and Oni, O.B.: Assessment of the role of mass media in the dissemination of agricultural technologies among farmers in Kaduna north local government area of Kaduna State, Nigeria. p 22-24 Journal of Biology, Agriculture and Healthcare (2013). Retrieved from:

http://www.iiste.org/Journals/index.php/JBAH/article/viewFile/5677/5790

[22] Lucas, F..: “A Radio Broadcasting Model for Rural Women and Farm Households”. FAO. January, 1999. Retrieved from: http://www.fao.org/docrep/005/ac789e/AC789E00.htm\#TOC

[23] Stewart, R., Langer, L., Da Silva, N.R., Muchiri, E.: Effects Of Training, Innovation and New Technology on African Smallholder Farmers' Economic Outcomes and Food Security. Systematic Review Summary 6. p 10-15. 3ie International Initiative for Impact Evaluation, UK (2016). Retrieved from: http://www.3ieimpact.org/media/filer_public/2016/07/14/srs6africa-smallholder-farmers.pdf

[24] Author unknown: Planting seeds for change. Billions in Change. (2017) Retrieved from:

www.billionsinchange.com/solutions/agriculture/

[25] Author unknown: United Nations Global Pulse website. (2017) Retrieved from: www.unglobalpulse.org/

[26] Author unknown: Biosecurity for agriculture and food production. Food and Agriculture Organization of the United Nation. (2017) Retrieved from: http://www.fao.org/biosecurity/ 
[27] Video: Africa 2016 - rethinking agriculture. World Economic Forum. (2016) Retrieved from:

www.youtube.com/watch?v=q1nppAYq-ew

[28] Author unknown: Fairtrade Africa website. (2017). Retrieved from: www.fairtradeafrica.net/

[29] Video: Agriculture, water and climate change in Africa. (2014) Retrieved from: www.youtube.com/watch?v=Vp8coUMPlJg

[30] Woodward, J.: Interactive radio for development projects: a toolkit for practitioners. U.S. Agency for International

Development's (USAID) and FHI 360. (2012). Retrieved from: www.ictforag.org/toolkits/index.html

[31] Sunga, I.: These 5 innovations will transform the lives of smallholder farmers. World Economic Forum. January 5, 2017.

Retrieved from: www.weforum.org/agenda/2017/01/these-5-innovations-will-transform-the-lives-of-smallholder-farmers/

[32] Biteye, M.: 70\% of Africans make a living through agriculture, and technology could transform their world. World

Economic Forum. May 6, 2016. Retrieved from: www.weforum.org/agenda/2016/05/70-of-africans-make-a-living-through-

agriculture-and-technology-could-transform-their-world/

[33] Saito, K.: How can satellite technology help African farmers?. World Economic Forum. November 3, 2015. Retrieved from: www.weforum.org/agenda/2015/11/how-can-satellite-technology-help-african-farmers/

[34] Patel, B.: 4 factors holding back Africa's small-scale farmers. World Economic Forum. May 10, 2016. Retrieved from: www.weforum.org/agenda/2016/05/4-factors-holding-back-african-farmers

[35] Coleman, G.: How Africa can lead the way in the Fourth Industrial Revolution. World Economic Forum. May 5, 2016.

Retrieved from: www.weforum.org/agenda/2016/05/how-africa-can-lead-the-way-in-the-fourth-industrial-revolution

[36] Gray, A.: African farmers need investment - but these 6 factors stand in the way. World Economic Forum. May 2, 2016.

Retrieved from: www.weforum.org/agenda/2016/05/6-challenges-to-investing-in-african-farmers

[37] Von Durging, M., Shakhovskoy, M., Zook, D.: Smallholder farmers are investable. Impact Alpha Medium blog. August 8,

2017.Retrieved from: https://news.impactalpha.com/smallholder-farmers-are-investable-5d2169b597b8

[38] Author unknown: GSMA website. (2017) Retrieved from: www.gsma.com/mobilefordevelopment/programmes/magri

[39] Roston, E.: There's a Climate Bomb Under Your Feet. Bloomberg. October 6, 2017. Retrieved from:

www.bloomberg.com/news/articles/2017-10-06/there-s-a-climate-change-bomb-under-your-

feet?utm_campaign=news\&utm_medium=bd\&utm_source=applenews

[40] Ehui, S.: How can we help smallholder farmers seize opportunities in Africa?. World Bank Africa Can End Poverty blog.

December 13, 2016. Retrieved from: http://blogs.worldbank.org/africacan/how-can-we-help-smallholder-farmers-seize-

opportunities-in-africa

[41] Kilibata, A.: Africa's Smallholder Farmers Among The Most Hurt By Climate Change. Huffington Post. November 25, 2016. Retrieved from: www.huffingtonpost.com/dr-agnes-kalibata/africas-smallholder-farme_b_13222494.html 
[42] SAP News.: SAP Launches SAP Rural Sourcing Management Solution to Support and Grow Smallholder Farmers in Developing Countries. SAP. May 4, 2017. Retrieved from: ww.news.sap.com/africa/2017/05/04/sap-launches-saprural-sourcing-management-solution-to-support-and-grow-smallholder-farmers-in-developing-countries/

\section{Acknowledgments}

This research was supported by members of A Growing Culture, Kikandwa Environmental Association, farmers from the village of Kasejjere, Uganda and graduate students at Columbia University. Columbia University also provided grant support for travel costs. A special thanks to all who shared their knowledge, time and financial support..

\section{KEA}

John Kaganga

Farmers

Leonard Buuma

Salongo Kakembo Ziboyumu

Steven Kiranda

\section{Researchers}

Celine Gaasrud

Amanda Stevens
Seruzi Alexander

Nakanwagi Correti

Joseph Bukya

Katsushaba Simon

Leticia Neves

Alyssa Watt
Geofrey Kizito

\author{
Mubiru "Bam" Hillary \\ Margaret Nabatanzi \\ Salongo Kamya Jackson
}

Sargam Saraf

Sarah Young 